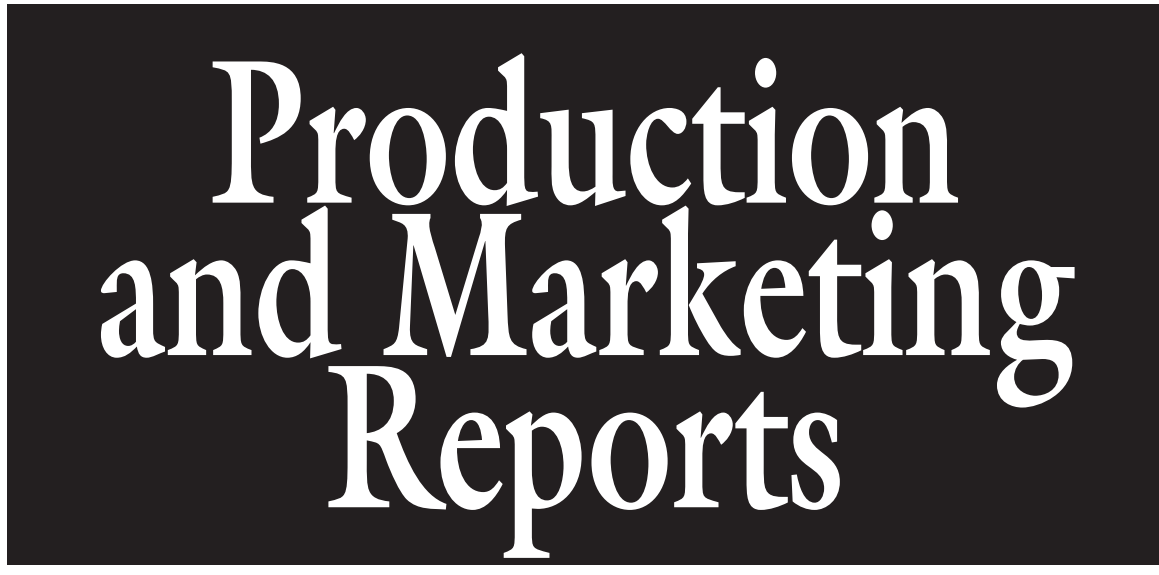

\title{
Industry Survey of the Native Wildflower Market in Florida
}

\author{
Philip J. Kauth and Hector E. Pérez ${ }^{1}$
}

ADDITIONAL INDEX WORDs. education, germination, research, seed conditioning, seed storage

SUMMARY. Native plant sales have increased steadily during the past decade because of consumer concern with invasive plant sales, water conservation, and land management issues. However, native plants are still under-used mostly because of a small market and the lack of education on the use and care of native plants. For example, native plant sales in Florida accounted for only $11 \%$ of the total horticultural market in 2005 . Within the Florida native plant industry, a small, but competitive market focuses on native wildflowers, but a paucity of information related to opportunities within this segment exists. We sent surveys to 137 members of the Florida native plant industry to learn about their interests, concerns, and trends in the native wildflower market. Survey respondents identified low demand, seed supply, and availability of desired species, plus insufficient customer and industry education as major factors limiting Florida native wildflower (FNW) sales. An overwhelming majority predicted that sales for locally produced FNWs would increase over the next 5 years. Respondents also stated that seed germination, seed storage, and seed production research are vital for the advancement of the industry. This survey provides an excellent opportunity to analyze the current native wildflower market and identify areas to help increase awareness of FNWs.

$\mathrm{T}$ he horticulture industry, specifically in Florida, has been one of the fastest growing industries in the United States (Hodges, 2011). For example, total horticulture industry sales in Florida, which includes wholesale nurseries ( $\$ 1.46$ billion), horticultural retailers ( $\$ 1.75$ billion $)$, and landscape services ( $\$ 2.70$ billion) increased from $\$ 5.9$ billion in 1997

\footnotetext{
Plant Restoration and Conservation Horticulture Research Consortium, Environmental Horticulture Department, University of Florida, PO Box 110675 Gainesville, FL 32611-0675

We thank the Florida Wildflower Foundation for providing financial support (R-006-09) to conduct this research, the Florida Association of Native Nurseries for allowing us to send the survey to workshop participants, and Charles R. Hall and anonymous reviewers for their constructive comments.

${ }^{1}$ Corresponding author. E-mail: heperez@ufl.edu.
}

to $\$ 15.2$ billion in 2005 (Hodges and Haydu, 2000, 2006). In 2008, wholesale nursery industry sales value in Florida was estimated at $\$ 3.52$ billion (Hodges, 2011). With support from the federal government, state agencies, and private organizations, the use of native plants has been a growing segment in the horticulture industry (Executive Order 13112, 1999; National Wildlife Federation, 2007; Peppin et al., 2010; Richards et al., 1998; Tamimi, 1999). In 2004, native plant sales comprised 13\% of total horticulture sales in the United States (Brooker et al., 2005). Native plant sales accounted for $19 \%$ of total plant sales in Florida during 2008 (Hodges, 2011).

Water management issues (Potts et al., 2002), land restoration and management practices (Curtis et al., 2005; Peppin et al., 2010), concerns about invasive ornamentals (Gagliardi and Brand, 2007; Yue et al., 2011), and landscape architects' demands and recommendations (Brzuszek and Harkess, 2009; Brzuszek et al., 2007) are major influences on native plant sales. Although gaining in popularity, native plants are still under-used because of a small market, nurseries with limited production and capital, higher prices for plant materials, lack of familiarity with native plants, and the misconception that natives are not as ornamental as nonnatives (Norcini, 2006). Of these concerns, lack of knowledge and education regarding the use and identification of native plants is a major concern for both the industry and consumers (Brzuszek and Harkess, 2009; Peppin et al., 2010; Pérez et al., 2010; Potts et al., 2002).

Within the native plant industry, a small market focuses on the sale of annual and perennial wildflowers (Pérez et al., 2010). In Florida, native plant industry members typically produce and grow FNWs from seeds. Native wildflowers and seeds, in turn, are often used for revegetation, restoration, erosion control, and highway beautification projects (Harper-Lore and Wilson, 2000; Lowery, 1983; Milstein, 2005; Pérez et al., 2010). The wildflower industry has not only become popular in the last 30 years, but the industry is highly competitive (Milstein, 2005). From recent conversations with industry members, major concerns limiting the FNW market include lack of shared knowledge, concerns about plant material origin and source, and seedprocessing issues. The purpose of this survey was to learn about the native plant industry's attitude toward native wildflowers. Specifically, we were interested in the industry's knowledge

\begin{tabular}{llll}
\hline $\begin{array}{l}\text { Units } \\
\begin{array}{l}\text { To convert U.S. to SI, } \\
\text { multiply by }\end{array}\end{array}$ & U.S. unit & SI unit & $\begin{array}{l}\text { To convert SI to U.S., } \\
\text { multiply by }\end{array}$ \\
\hline 0.4047 & acre $(s)$ & ha & 2.4711 \\
1.6093 & mile $(s)$ & $\mathrm{km}$ & 0.6214
\end{tabular}


about FNW propagation and production via seeds as well as the current and future trends for native wildflowers.

\section{Materials and methods}

We developed a 24-question survey (Table 1 ) for native plant nurseries in Florida. A total of 137 potential survey participants were identified through the Association for Florida Native Nurseries (AFNN) Native Plant Directory, The AFNN Guide for Real Florida Gardeners, University of Florida Institute of Food and Agricultural Sciences Extension Services (Vasquez and Haynes, n.d.), and Alabama Cooperative Extension System for Florida panhandle growers (Alabama Cooperative Extension System, n.d.). The sample of 137 nurseries represents all nurseries listed in the previously mentioned directories. We mailed 97 paper surveys to potential participants on 10 Feb. 2011. To facilitate survey returns, we included a postage-paid business reply envelope in each mail out. In addition, we offered the survey to 40 participants of an AFNN workshop in Kissimmee, FL on 28 Jan. 2011. We emailed the survey $2 \mathrm{~d}$ before the workshop and instructed participants to bring the survey to the workshop. To avoid duplication of survey results, we asked workshop participants to complete the paper delivered survey only if they had not returned the e-mail survey. The questions on the paper survey and e-mail survey were identical. In total, we sent 137 surveys. We sent a reminder e-mail to survey recipients on 28 Feb. 2011 (Dillman, 2000).

We provided definitions of FNWs, seed conditioning, certified seed, and genetic origin for the survey participants. We defined FNWs as annual or perennial herbaceous species indigenous to Florida (Pérez et al., 2010). We defined seed conditioning as "processing seeds to remove unwanted material or contaminants such as pathogens, weed seeds, debris, and poor quality seed" (Black et al., 2006). Certified seed was defined as "seeds produced under strict seed standards to maintain seeds free of debris and prohibited weed seeds" (Black et al., 2006). Finally, we defined genetic origin as the location where the native plant material was first collected. The survey included five areas pertaining to the native plant industry: 1) business demographics, 2) FNW offerings, 3 ) aspects of seed propagation and production, 4) limitations and concerns in the industry, and 5) future trends.

We measured respondents' level of agreement or disagreement to survey questions using a five-point Likerttype rating scale. Additionally, we asked open-ended questions about definitions and seed-processing methods. Excel (version 12; Microsoft, Redmond, WA) was used to generate frequencies, contingency tables, and conduct

\section{Table 1. Questions included in the 2011 survey of native wildflower producers in Florida.}

1) How many years have you been involved in the native plant industry?

2) What types of services do you provide to the native plant industry: producer, grower, seller, contract work, consulting, plant material collection, wholesaler, retailer, maintenance, other?

3) What was your total gross revenue (\$) from plant sales in 2010 ?

4) In 2010, how many total acres did you have in production? ${ }^{z}$

5 ) What percent of your stock are native Florida plants?

6) How do you define a Florida native wildflower?

7) Do you offer Florida native wildflowers?

8) What is the source of your Florida native wildflowers: wild collection, on-site collection, in-state seed producer, out-of-state seed producer, in-state grower, out-of-state grower, other?

9) Who buys the majority of your Florida native wildflowers: federal government, state government, in-state organizations, out-of-state organizations, on-site customers, other?

10) What percentage of your Florida native wildflowers are grown from seed?

11) How important are the following to help increase production and sales of Florida native wildflowers: new species development, new market development, seed germination research, educating the public, educating the industry, lower prices, accurate labeling, reliable seed supply?

12) How difficult are the following: finding buyers, seed germination, seed collection, seed conditioning, breaking seed dormancy, testing seed viability, maintaining viability of stored seed?

13) How important are these factors to the Florida native wildflower market: cost of materials too high, demand too low, seed supply too low, desired species not available, customers unfamiliar with wildflower care, confusion over what is native, demand growing faster than supply, lack of knowledgeable labor?

14) How do you define ecotype: within 50 miles, within county, within region, within state, other? ${ }^{2}$

15) How concerned are you with the genetic origin of plant materials?

16) How do you define seed quality?

17) How likely are you to purchase certified seed given a price increase of: $10 \%, 20 \%, 30 \%, 40 \%, 50 \%, 60 \%, 70 \%, 80 \%, 90 \%$, or $100 \%$ ?

18) How much value does seed conditioning add to wildflower production?

19) Do you collect your own native wildflower seeds?

20) Do you condition your own native wildflower seeds?

21) Do you store native wildflower seeds?

22) What are your expectations of Florida native wildflower seed production over the next 5 years?

23) How important is the need for local Florida native wildflowers?

24) Rate the following areas of research: seed germination, seed conditioning, seed storage, breaking seed dormancy, increasing seed production, increasing wildflower production, determining new wildflower combinations, new species development, ecology/local adaptation?

${ }^{2} 1$ acre $=0.4047$ ha, 1 mile $=1.6093$ ha. 
Pearson's chi-square test of the response data. Answer frequencies and sample sizes were calculated for each question. Questions without responses were not included in the calculations creating an uneven sample size for some questions. The MULTINOM procedure of SAS (version 9.1; SAS Institute, Cary, NC) was used to compare the probabilities of all response levels and to generate all pairwise comparisons. The Bonferroni adjustment was applied to the intervals of pairwise comparisons and hypothesis tests to achieve a simultaneous $95 \%$ confidence level.

\section{Results}

Of the 137 surveys sent, 51 were returned (37.2\% response rate). Thirty were returned by standard mail $(22.9 \%$ response rate), and 21 were returned from the workshop participants $(52.5 \%$ response rate). Of the businesses solicited, 93 were members of AFNN, 50 were members of the Florida Nursery, Growers and Landscape Association (FNGLA), and 45 were members of both organizations.

Demographics. About 35\% of the survey respondents stated they have been involved in the native plant industry for more than 20 years, while only $6.1 \%$ had been involved less than 1 year (Table 2). Survey participants served multiple roles in the industry, but most classified themselves as growers $(76.0 \%)$, sellers $(54.0 \%)$, wholesale businesses $(66.0 \%)$, and/or retail businesses $(50.0 \%)$. The majority of the nurseries were less than 10 acres in size $(71.7 \%)$. About $32 \%$ reported total gross revenues under $\$ 25,000$ from plant sales, but $\approx 21 \%$ had sales between $\$ 50,000-100,000$ and over $\$ 500,000$ (Table 2).

FNW Questions. Almost 57\% of the survey respondents indicated their nursery stock consisted of $81 \%$ to $100 \%$ native FL plants, and $78.4 \%$ offered FNWs. These values were significantly different from remaining responses (Tables 3 and 4). Of the businesses that offer FNWs, $51.5 \%$ indicated that $0 \%$ to $10 \%$ of their total nursery stock were FNWs. The majority of businesses obtain their FNWs from on-site collections $(78.0 \%)$, wild collections $(61.0 \%)$, or in-state growers $(48.8 \%)$ and seed producers (48.8\%). Several nurseries obtained FNWs from either out-of-state growers $(4.9 \%)$ or seed producers (14.6\%) (Tables 2 and $3)$. On-site purchases accounted for

Table 2. Demographic profile of Florida native plant producers involved in the Florida native wildflower (FNW) plant market during 2011.

\begin{tabular}{|c|c|}
\hline$\underline{\text { Respondent characteristic }}$ & Response (\%) \\
\hline \multicolumn{2}{|c|}{ Years in native plant industry $(n=49)$} \\
\hline$<$ l year & 6.1 \\
\hline $1-5$ years & 16.3 \\
\hline $6-10$ years & 14.3 \\
\hline $11-15$ years & 14.3 \\
\hline $16-20$ years & 14.3 \\
\hline$>20$ years & 34.7 \\
\hline \multicolumn{2}{|c|}{ Total gross revenue $(\mathrm{K}=\$ 1000)$ in $2010(n=44)$} \\
\hline$<\$ 25 \mathrm{~K}$ & 31.8 \\
\hline$\$ 25 \mathrm{~K}-\$ 50 \mathrm{~K}$ & 4.5 \\
\hline$\$ 50 \mathrm{~K}-\$ 100 \mathrm{~K}$ & 20.5 \\
\hline$\$ 100 \mathrm{~K}-\$ 250 \mathrm{~K}$ & 13.6 \\
\hline$\$ 250 \mathrm{~K}-\$ 500 \mathrm{~K}$ & 9.1 \\
\hline$>\$ 500 \mathrm{~K}$ & 20.5 \\
\hline \multicolumn{2}{|c|}{ Total acres in production $(n=46)^{\mathrm{z}}$} \\
\hline$<10$ acres & 71.7 \\
\hline $11-25$ acres & 10.9 \\
\hline $26-50$ acres & 13.0 \\
\hline $51-75$ acres & 2.2 \\
\hline $76-100$ acres & 2.2 \\
\hline$>100$ acres & 0.0 \\
\hline \multicolumn{2}{|l|}{ Major buyers of FNWs $(n=37)$} \\
\hline Federal government & 8.1 \\
\hline State government & 10.8 \\
\hline In-state organizations & 37.8 \\
\hline Out-of-state organizations & 13.5 \\
\hline On-site customers & 67.6 \\
\hline Other & 27.0 \\
\hline \multicolumn{2}{|l|}{ Sources of FNWs $(n=41)^{\mathrm{y}}$} \\
\hline Wild collection & 61.0 \\
\hline On-site collection & 78.0 \\
\hline In-state seed producer & 48.8 \\
\hline Out-of-state seed producer & 14.6 \\
\hline In-state grower & 48.8 \\
\hline Out-of-state grower & 4.9 \\
\hline Other & 12.5 \\
\hline \multicolumn{2}{|c|}{ Types of services provided $(n=50)^{\mathrm{y}}$} \\
\hline Producer & 26.0 \\
\hline Grower & 76.0 \\
\hline Seller & 54.0 \\
\hline Contract work & 22.0 \\
\hline Consulting & 32.0 \\
\hline Collect plant material & 28.0 \\
\hline Wholesaler & 66.0 \\
\hline Retailer & 50.0 \\
\hline Landscape maintenance & 30.0 \\
\hline Other & 20.0 \\
\hline \multicolumn{2}{|l|}{ Top five selling FNWs $(n=40)^{\mathrm{x}}$} \\
\hline Firewheel & 50.0 \\
\hline Dune sunflower & 50.0 \\
\hline Tropical sage & 35.0 \\
\hline Leavenworth's tickseed & 22.5 \\
\hline Powderpuff & 22.5 \\
\hline
\end{tabular}

$67.6 \%$ of sales, while private in-state organizations made up $37.8 \%$ of sales. Other customers included landscapers, restoration consultants, and city, state, and county governments. We asked participants to identify their top five 
Table 3. Proportion of plant inventory devoted to Florida native plants and native wildflowers (FNW) estimated by Florida native plant producers in 2011 .

\begin{tabular}{|c|c|c|c|c|c|c|c|}
\hline \multirow[b]{2}{*}{ Inventory characteristic } & \multicolumn{7}{|c|}{ Response } \\
\hline & $0 \%$ to $10 \%$ & $11 \%$ to $20 \%$ & $21 \%$ to $40 \%$ & $41 \%$ to $60 \%$ & $61 \%$ to $80 \%$ & $81 \%$ to $100 \%$ & $\begin{array}{c}\text { Not } \\
\text { certain }\end{array}$ \\
\hline $\begin{array}{l}\text { Percentage of stock in native } \\
\text { Florida plants }(n=46)\end{array}$ & $10.9 \mathrm{~b}^{\mathrm{z}}$ & $10.9 \mathrm{~b}$ & $0.0 \mathrm{~b}$ & $6.5 \mathrm{~b}$ & $13.0 \mathrm{~b}$ & $56.5 \mathrm{a}$ & $2.2 \mathrm{~b}$ \\
\hline$\chi^{2}=71.388, \mathrm{df}=6, P<0.0001$ & & & & & & & \\
\hline $\begin{array}{l}\text { Percentage of stock in FNW } \\
\qquad \begin{array}{l}(n=33) \\
\chi^{2}=39.057, \mathrm{df}=5, P<0.0001\end{array}\end{array}$ & $51.5 \mathrm{a}$ & $3.0 \mathrm{bc}$ & $15.2 \mathrm{abc}$ & $0.0 \mathrm{c}$ & $0.0 \mathrm{bc}$ & $27.3 \mathrm{ab}$ & $-^{y}$ \\
\hline $\begin{array}{l}\text { Percentage of FNW grown from } \\
\text { seed }(n=38) \\
\chi^{2}=10.064, \mathrm{df}=5, P=0.0735\end{array}$ & $10.5 \mathrm{a}$ & $15.8 \mathrm{a}$ & $7.9 \mathrm{a}$ & $13.2 \mathrm{a}$ & $18.4 \mathrm{a}$ & $34.2 \mathrm{a}$ & $-^{\mathrm{y}}$ \\
\hline
\end{tabular}

Table 4. Proportion of Florida native plant producers that offer Florida native wildflowers (FNWs) in 2011 and their habits related to collecting, storing, and conditioning native wildflower seeds.

\begin{tabular}{|c|c|c|}
\hline \multirow[b]{2}{*}{ Habit } & \multicolumn{2}{|c|}{ Response (\%) } \\
\hline & Yes & No \\
\hline $\begin{array}{l}\text { Offer FNWs }(n=51) \\
\quad \chi^{2}=16.490, \mathrm{df}=1, P<0.0001\end{array}$ & $78.4 \mathrm{a}^{\mathrm{z}}$ & $21.6 \mathrm{~b}$ \\
\hline $\begin{array}{l}\text { Collect own FNW seeds }(n=51) \\
\chi^{2}=0.961, \mathrm{df}=1, P=0.3270\end{array}$ & $56.9 \mathrm{a}$ & $43.1 \mathrm{a}$ \\
\hline $\begin{array}{l}\text { Store own FNW seeds }(n=51) \\
\quad \chi^{2}=0.490, \mathrm{df}=1, P=0.4838\end{array}$ & 54.9 a & $45.1 \mathrm{a}$ \\
\hline $\begin{array}{c}\text { Condition own FNW seeds }(n=51) \\
\chi^{2}=10.373, \mathrm{df}=1, P=0.0013\end{array}$ & $27.5 \mathrm{~b}$ & $72.5 \mathrm{a}$ \\
\hline
\end{tabular}

${ }^{2}$ Percentage analysis and mean separation within a row conducted using Pearson's chi-square test and the MULTINOM (SAS version 9.1; SAS Institute, Cary, NC) procedure at $P \leq 0.05$, respectively.

selling FNWs. Respondents listed 46 species as the top selling FNWs, but firewheel (Gaillardia pulchella), dune sunflower (Helianthus debilis), tropical sage (Salvia coccinea), leavenworth's tickseed (Coreopsis leavenworthii), and powderpuff (Mimosa strigillosa) garnered the most responses (Table 2).

Seed-Related Questions. About $34 \%$ indicated that $81 \%$ to $100 \%$ of their FNWs were seed-grown, while only $10.5 \%$ of respondents had a small portion ( $0 \%$ to $10 \%)$ of seedgrown FNWs (Table 3 ). A majority $(56.9 \%)$ collected their own seed supply with $100 \%$ of respondents collecting seed by hand. Only $6.9 \%$ of respondents used a mechanical harvesting system. Many respondents $(54.9 \%)$ indicated that they store wildflower seeds. Only $27.5 \%$ of respondents indicated that they condition their own seeds. About $61 \%$ of respondents indicated that seed conditioning provided some degree of value $($ mean $=$ 3.8 on a scale of $1-5$ with 5 being high value) to wildflower production, while
$13.2 \%$ indicated that conditioning added little value (Tables 4 and 5 ). About $47 \%$ of respondents classified an ecotype as living within the region. However, respondents did not provide a definition of region. Only $10.4 \%$ were unconcerned about the genetic origin of their plant material, while most were either concerned $(22.9 \%)$ or very concerned (33.3\%) (Table 5). A majority $(54.0 \%)$ also indicated they were willing to purchase certified seed over noncertified seed up to a $50 \%$ premium. While some respondents (41.0\%) were likely to purchase certified seed at an $80 \%$ to $100 \%$ (mean $=2.76$ on a scale of $1-5$ with 5 being most likely to purchase) premium, more were not likely $(52 \% \pm 3 \%)$ to purchase certified seed at this price point (Table 6).

CURRENT TRENDS. We identified eight factors that influence the FNW market and asked respondents to rate these factors (Table 7). Very few respondents expressed concern about high material costs, lack of knowledgeable labor, or demand outpacing supply. Most were concerned with low demand (56.4\%) and seed supply $(53.8 \%)$, lack of desired species $(76.9 \%)$, customers' unfamiliarity with FNWs (62.5\%), and customer confusion about what constitutes "native" (64.1\%). Of these factors, respondents rated the lack of desired species $($ mean $=4.03$ on a scale of $1-5$ with 5 being serious limitation) as the most serious limitation to the FNW market. Pairwise comparisons revealed that responses to the question of species availability categorized as being a serious limitation or a limitation were significantly different from responses categorized as being of little or no limitation (Table 7).

We also asked participants to provide rate scores for factors they feel would help increase FNW production and sales (Table 8). Of these factors, respondents were least concerned with lower prices, while education of both the public and industry rated highly. Respondents identified public $(76.7 \%)$ and industry $(70.5 \%)$ education as very important factors. These responses were significantly different from responses grouped into the remaining categories. Only $11.6 \%$ responded that lower prices were very important to promote FNWs, but 32.6\% said lower prices were not important. A statistically significant majority of respondents indicated that reliable seed sources and accurate labeling were very important factors. Nearly $40 \%$ and $30 \%$ thought seed germination research and new species development, respectively, were very important factors. The former response being significantly different from responses categorized as being of little or no importance. About 
Table 5. Florida native wildflower producer seed collection methods, definition of ecotype, concern with genetic origin of plant material, and opinion regarding added value of seed conditioning and future trends in the Florida native wildflower (FNW) market in 2011.

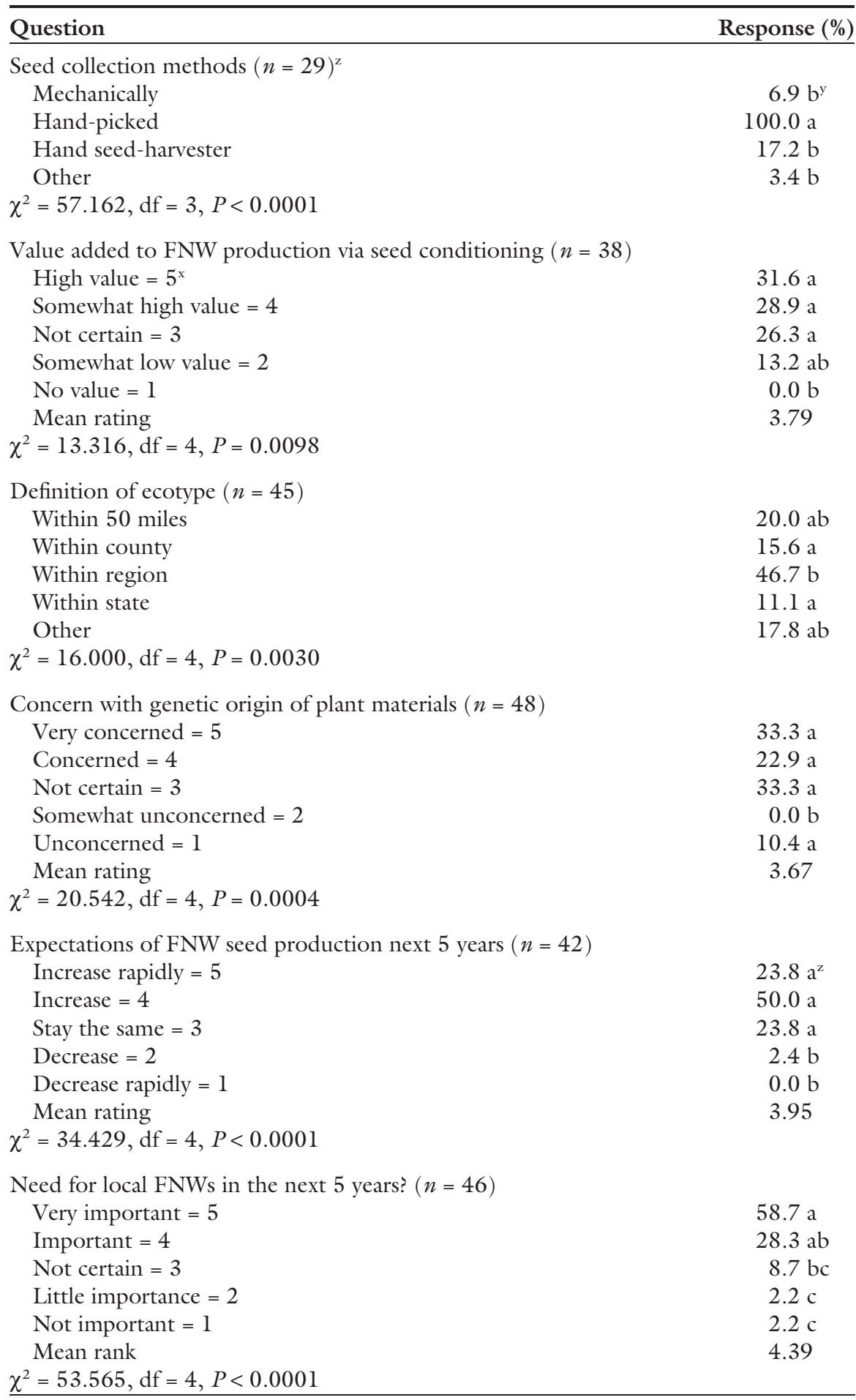

${ }^{\mathrm{z}}$ Many respondents checked more than one answer.

yercentage analysis and mean separation within subgroups in the column conducted using Pearson's chi-square test and the MULTINOM procedure (SAS version 9.1; SAS Institute, Cary, NC) at $P \leq 0.05$, respectively.

${ }^{x}$ Numerical value assigned to each response category in a five-point Likert-type rating scale.

$23 \%$ did not identify new species development as important (Table 8 ).

Twenty percent of respondents indicated that seed conditioning, breaking seed dormancy, testing seed viability, and maintaining seed viability were very difficult (Table 9). However, $51.4 \%$ and $50.0 \%$ said that maintaining seed viability and breaking dormancy, respectively, had some level of difficulty. About $49 \%$ thought that finding buyers was difficult or very difficult. Very few thought any of the factors were easy or very easy, but $32.3 \%$ thought that seed germination was easiest of the factors.

Future trends. We asked the participants about their expectations of the FNW industry over the next 5 years. Fifty percent expected FNW seed production to increase, and $23.8 \%$ expected production to increase rapidly or stay the same. Only $2.4 \%$ expected production to decrease. No respondents thought production would decrease rapidly. Almost 59\% indicated that the need for locally produced FNWs was very important over the next 5 years. Only $4.4 \%$ foresaw little or no need for local FNW production. A majority indicated that the nine areas of research listed were important or very important. Of these areas, respondents gave seed germination $(85.4 \%)$, seed storage $(80.5 \%)$, and increasing both seed $(82.9 \%)$ and wildflower $(84.6 \%)$ production the highest scores (Tables 5 and 10 ).

Open-ended Questions. We asked survey participants to provide answers to several open-ended questions including definitions of a FNW and seed quality and their methods for storing and conditioning seeds (Table 11). Most respondents defined a FNW as a wildflower found in Florida before the arrival of Europeans or a plant indigenous to Florida. Seven respondents included herbaceous in the definition, and three specifically stated that a FNW is a native flowering plant that attracts wildlife. Six respondents included adaptation to its ecosystem or natural area as criteria for a FNW.

When asked to define seed quality, most included high viability as the top criteria (Table 11). High germination, true to type, and weed/debris free were also popular answers. Four respondents defined quality seed as fresh. Only 14 responded with methods for conditioning seeds. Four condition seeds by hand, four use a series of sieves, and two use mechanical or air cleaning devices to condition seeds. Finally, we asked the respondents how they store FNW seed (Table 11). Fourteen store seeds in paper bags, while six use plastic bags or containers. Twelve refrigerate seeds, while eight store seeds at room temperature. Five respondents indicated that they store them dry (Table 11). Only five indicated the length of time 
Table 6. Likelihood of Florida native wildflower producers to purchase certified seed given a specific percent increase in price over noncertified seed $(n=37)$

\begin{tabular}{|c|c|c|c|c|c|c|}
\hline \multirow[b]{2}{*}{ Increase (\%) } & \multicolumn{5}{|c|}{ Response (\%) } & \multirow[b]{2}{*}{ Mean rating } \\
\hline & Very likely, $\mathbf{5}^{z}$ & Likely, 4 & Not certain, 3 & Probably not, 2 & Not likely, 1 & \\
\hline 10 & $78.4 \mathrm{a}^{\mathrm{y}}$ & $5.4 \mathrm{~b}$ & $0.0 \mathrm{~b}$ & $5.4 \mathrm{~b}$ & $10.8 \mathrm{~b}$ & 4.35 \\
\hline 30 & $56.8 \mathrm{a}$ & $13.5 \mathrm{~b}$ & $16.2 \mathrm{~b}$ & $2.7 \mathrm{~b}$ & $10.8 \mathrm{~b}$ & 4.03 \\
\hline 40 & $40.5 \mathrm{a}$ & $13.5 \mathrm{ab}$ & $10.8 \mathrm{~b}$ & $13.5 \mathrm{ab}$ & $21.6 \mathrm{a}$ & 3.38 \\
\hline 50 & $37.8 \mathrm{a}$ & $16.2 \mathrm{ab}$ & $8.1 \mathrm{~b}$ & $16.2 \mathrm{ab}$ & $21.6 \mathrm{ab}$ & 3.32 \\
\hline 80 & $32.4 \mathrm{ab}$ & $8.1 \mathrm{c}$ & $10.8 \mathrm{bc}$ & $10.8 \mathrm{bc}$ & $37.8 \mathrm{a}$ & 2.86 \\
\hline 90 & $27.0 \mathrm{a}$ & $13.5 \mathrm{a}$ & $5.4 \mathrm{~b}$ & $13.5 \mathrm{a}$ & $40.5 \mathrm{a}$ & 2.73 \\
\hline 100 & $29.7 \mathrm{ab}$ & $10.8 \mathrm{a}$ & $5.4 \mathrm{a}$ & $8.1 \mathrm{a}$ & $45.9 \mathrm{~b}$ & 2.70 \\
\hline
\end{tabular}

${ }^{2}$ Numerical value assigned to each response category in a five-point Likert-type rating scale.

'Percentage analysis and mean separation within a row conducted using Pearson's chi-square test and the MULTINOM procedure (SAS version 9.1; SAS Institute, Cary, NC) at $P \leq 0.05$, respectively.

Table 7. Potential limiting and nonlimiting factors to the native wildflower market identified by native plant producers $(n=39)$ in Florida during 2011.

\begin{tabular}{|c|c|c|c|c|c|c|}
\hline \multirow[b]{2}{*}{ Factor } & \multicolumn{5}{|c|}{ Response (\%) } & \multirow[b]{2}{*}{$\begin{array}{l}\text { Mean } \\
\text { rating }\end{array}$} \\
\hline & $\begin{array}{c}\text { Serious } \\
\text { limitation, } 5^{\mathrm{z}}\end{array}$ & Limitation, 4 & $\begin{array}{c}\text { Not } \\
\text { certain, } 3\end{array}$ & $\begin{array}{c}\text { Little } \\
\text { limitation, } 2\end{array}$ & $\begin{array}{c}\text { No } \\
\text { limitation, } 1\end{array}$ & \\
\hline Cost of materials too high & $5.1 \mathrm{a}^{\mathrm{y}}$ & $20.5 \mathrm{a}$ & $28.2 \mathrm{a}$ & $25.6 \mathrm{a}$ & $20.5 \mathrm{a}$ & 2.65 \\
\hline Demand too low & $23.1 \mathrm{a}$ & $33.3 \mathrm{a}$ & $25.6 \mathrm{a}$ & $10.3 \mathrm{a}$ & $7.7 \mathrm{a}$ & 3.54 \\
\hline Seed supply too low & $25.6 \mathrm{a}$ & $28.2 \mathrm{a}$ & $25.9 \mathrm{a}$ & $10.3 \mathrm{ab}$ & $0.0 \mathrm{~b}$ & 3.69 \\
\hline Desired species not available & $41.0 \mathrm{a}$ & 35.9 a & $12.8 \mathrm{ab}$ & $5.1 \mathrm{~b}$ & $5.1 \mathrm{~b}$ & 4.03 \\
\hline Demand growing faster than supply & $15.4 \mathrm{a}$ & $15.4 \mathrm{a}$ & $35.9 \mathrm{a}$ & $12.8 \mathrm{a}$ & $20.5 \mathrm{a}$ & 2.92 \\
\hline $\begin{array}{l}\text { Lack of knowledgeable labor } \\
\qquad \chi^{2}=164.867, \mathrm{df}=28, P<0.0001\end{array}$ & $7.7 \mathrm{a}$ & $15.4 \mathrm{ab}$ & $35.9 \mathrm{~b}$ & $23.1 \mathrm{ab}$ & $17.9 \mathrm{ab}$ & 2.72 \\
\hline
\end{tabular}

${ }^{2}$ Numerical value assigned to each response category in a five-point Likert-type rating scale.

'Percentage analysis and mean separation within a row conducted using Pearson's chi-square test and the MULTINOM procedure (SAS version 9.1; SAS Institute, Cary, NC) at $P \leq 0.05$, respectively.

Table 8. Importance of factors identified by native plant producers $(n=39)$ in Florida during 2011 that are expected to increase production and sales of native wildflowers.

\begin{tabular}{|c|c|c|c|c|c|c|}
\hline \multirow[b]{2}{*}{ Factor } & \multicolumn{5}{|c|}{ Repsonse (\%) } & \multirow[b]{2}{*}{$\begin{array}{l}\text { Mean } \\
\text { rating }\end{array}$} \\
\hline & $\begin{array}{c}\text { Very } \\
\text { important, } 5^{z}\end{array}$ & Important, 4 & $\begin{array}{c}\text { Not } \\
\text { certain, } 3\end{array}$ & $\begin{array}{c}\text { Little } \\
\text { importance, } 2\end{array}$ & $\begin{array}{c}\text { Not } \\
\text { important, } 1\end{array}$ & \\
\hline New species development $(n=44)$ & $29.5 \mathrm{a}^{\mathrm{y}}$ & $22.7 \mathrm{a}$ & $20.5 \mathrm{a}$ & $4.5 \mathrm{~b}$ & $22.7 \mathrm{a}$ & 3.28 \\
\hline New market development $(n=43)$ & $51.2 \mathrm{a}$ & $25.6 \mathrm{ab}$ & $18.6 \mathrm{ab}$ & $0.0 \mathrm{c}$ & $4.7 \mathrm{bc}$ & 4.19 \\
\hline Seed germination research $(n=43)$ & $39.5 \mathrm{a}$ & $20.9 \mathrm{abc}$ & $27.9 \mathrm{ab}$ & $4.7 \mathrm{c}$ & $7.0 \mathrm{bc}$ & 4.19 \\
\hline $\begin{array}{l}\text { Educate public on Florida native } \\
\text { wildflowers (FNWs) }(n=43)\end{array}$ & 76.7 a & $16.3 \mathrm{~b}$ & $7.0 \mathrm{bc}$ & $0.0 \mathrm{c}$ & $0.0 \mathrm{c}$ & 4.70 \\
\hline Lower prices $(n=43)$ & $11.6 \mathrm{a}$ & $9.3 \mathrm{a}$ & $30.2 \mathrm{a}$ & $16.3 \mathrm{a}$ & $32.6 \mathrm{a}$ & 2.51 \\
\hline Accurate labeling $(n=44)$ & $63.6 \mathrm{a}$ & $20.5 \mathrm{~b}$ & $11.4 \mathrm{~b}$ & $2.3 \mathrm{~b}$ & $2.3 \mathrm{~b}$ & 4.41 \\
\hline $\begin{array}{l}\text { Reliable seed supply }(n=44) \\
\quad \chi^{2}=275.03, \mathrm{df}=28, P<0.0001\end{array}$ & $61.4 \mathrm{a}$ & $20.5 \mathrm{~b}$ & $13.6 \mathrm{bc}$ & $4.5 \mathrm{bc}$ & $0.0 \mathrm{c}$ & 4.39 \\
\hline
\end{tabular}

${ }^{2}$ Numerical value assigned to each response category in a five-point Likert-type rating scale.

'Percentage analysis and mean separation within a row conducted using Pearson's chi-square test and the MULTINOM procedure (SAS version 9.1; SAS Institute, Cary, NC) at $P \leq 0.05$, respectively.

they store seeds ranging from 2 months to 5 years.

\section{Discussion}

As indicated by Florida native plant producers, the results of this survey revealed several limiting factors for the FNW market including: 1) education of customers and the industry, 2) accuracy of labeling, 3) reliability of seed sources, 4) need for new market development, and 5) availability of desired species. Although the FNW market is small and localized, the growing demand for native plant materials, in general, provides a solid avenue to promote the sale and use of FNWs. 
Table 9. Florida native plant producer opinion regarding the relative ease or difficulty of finding buyers and application of various seed technologies to native wildflower germplasm during 2011.

\begin{tabular}{|c|c|c|c|c|c|c|}
\hline \multirow[b]{2}{*}{ Factor } & \multicolumn{5}{|c|}{ Frequency (\%) } & \multirow{2}{*}{$\begin{array}{l}\text { Mean } \\
\text { rating }\end{array}$} \\
\hline & $\overline{\text { Very difficult, } \mathbf{5}^{\mathrm{z}}}$ & Difficult, 4 & Not certain, 3 & Easy, 2 & Very easy, 1 & \\
\hline Finding buyers $(n=39)$ & $12.8 \mathrm{a}^{\mathrm{y}}$ & $35.9 \mathrm{a}$ & $28.2 \mathrm{a}$ & $12.8 \mathrm{a}$ & $10.3 \mathrm{a}$ & 3.28 \\
\hline Seed collection $(n=34)$ & $17.6 \mathrm{a}$ & $26.5 \mathrm{a}$ & $38.2 \mathrm{a}$ & $8.8 \mathrm{a}$ & $8.8 \mathrm{a}$ & 3.35 \\
\hline Seed conditioning $(n=35)$ & $20.0 \mathrm{ab}$ & $25.7 \mathrm{ab}$ & $34.3 \mathrm{a}$ & $11.4 \mathrm{~b}$ & $8.6 \mathrm{~b}$ & 3.37 \\
\hline Breaking seed dormancy $(n=34)$ & $20.6 \mathrm{a}$ & $29.4 \mathrm{a}$ & $26.5 \mathrm{a}$ & $20.6 \mathrm{a}$ & $2.9 \mathrm{~b}$ & 3.44 \\
\hline
\end{tabular}

$\chi^{2}=35.591, \mathrm{df}=24, P=0.0480$

${ }^{\mathrm{z}}$ Numerical value assigned to each response category in a five-point Likert-type rating scale.

yPercentage analysis and mean separation within a row conducted using Pearson's chi-square test and the MULTINOM procedure (SAS version 9.1; SAS Institute, Cary, NC) at $P \leq 0.05$, respectively.

Table 10. Florida native plant producer opinion on important areas of research and future trends related to the Florida native wildflower market during 2011.

\begin{tabular}{|c|c|c|c|c|c|c|}
\hline \multirow[b]{2}{*}{ Factor } & \multicolumn{5}{|c|}{ Frequency (\%) } & \multirow[b]{2}{*}{$\begin{array}{l}\text { Mean } \\
\text { rating }\end{array}$} \\
\hline & $\begin{array}{c}\text { Very } \\
\text { important, } 5^{z}\end{array}$ & Important, 4 & $\begin{array}{c}\text { Not } \\
\text { certain, } 3 \\
\end{array}$ & $\begin{array}{c}\text { Little } \\
\text { importance, } 2\end{array}$ & $\begin{array}{c}\text { Not } \\
\text { important, } 1\end{array}$ & \\
\hline Seed conditioning $(n=41)$ & $46.3 \mathrm{a}$ & $24.4 \mathrm{ab}$ & $17.1 \mathrm{ab}$ & $12.2 \mathrm{bc}$ & $0.0 \mathrm{c}$ & 4.05 \\
\hline Seed storage $(n=41)$ & $56.1 \mathrm{a}$ & $24.4 \mathrm{ab}$ & $14.6 \mathrm{bc}$ & $2.4 \mathrm{c}$ & $2.4 \mathrm{c}$ & 4.29 \\
\hline Breaking seed dormancy $(n=41)$ & $53.7 \mathrm{a}$ & $24.4 \mathrm{ab}$ & $17.1 \mathrm{~b}$ & $0.0 \mathrm{c}$ & $4.9 \mathrm{bc}$ & 4.22 \\
\hline New wildflower combinations $(n=38)$ & $36.8 \mathrm{a}$ & $21.1 \mathrm{ab}$ & $26.3 \mathrm{ab}$ & $7.9 \mathrm{~b}$ & $7.9 \mathrm{~b}$ & 3.71 \\
\hline Commercialization of new species $(n=38)$ & $44.7 \mathrm{a}$ & $21.1 \mathrm{ab}$ & $21.1 \mathrm{ab}$ & $10.5 \mathrm{~b}$ & $2.6 \mathrm{~b}$ & 3.95 \\
\hline Ecology/local adaptation $(n=39)$ & $46.2 \mathrm{a}$ & $33.3 \mathrm{a}$ & $15.4 \mathrm{ab}$ & $5.1 \mathrm{~b}$ & $0.0 \mathrm{~b}$ & 4.21 \\
\hline
\end{tabular}

$\chi^{2}=82.067, \mathrm{df}=32, P<0.0001$

${ }^{\mathrm{z}}$ Numerical value assigned to each response category in a five-point Likert-type rating scale.

Percentage analysis and mean separation within a row conducted using Pearson's chi-square test and the MULTINOM procedure (SAS version 9.1; SAS Institute, Cary, NC) at $P \leq 0.05$, respectively.

Over half of the survey respondents indicated that $81 \%$ to $100 \%$ of their stock is Florida native plants. In a survey of southeastern U.S. nurseries, Brzuszek and Harkess (2009) reported that native plants comprised only $20 \%$ of nursery stock, but nurseries in Texas indicated $21 \%$ to $40 \%$ of their stock was native. In our study, we specifically targeted the native plant industry, so the large percentage of native plant offerings is not surprising. A large majority of the nurseries in our study offer FNWs as a component of their native plant sales, but FNWs only comprise a small percentage of the native plant market. This low percentage reflects the low availability of FNWs given that only five species comprised $\approx 48 \%$ of $\mathrm{FNW}$ offerings. We were surprised that new species development was not highly rated as an important factor to further the FNW market, but the industry indicated that the availability of desired species was important. We were also surprised that commercialization of new species did not rate as highly as other areas of research, such as seed processing.

The low FNW offerings could simply be due to demand. In our study, industry indicated that low demand was a limitation, and almost half of the survey respondents indicated that finding buyers was difficult or very difficult. Low customer demand has also been reported as a limitation in the native plant market in the southeastern United States (Brzuszek and Harkess, 2009; Brzuszek et al., 2007). Demand seems to be a regional issue. High demand is rather common in western states because government agencies purchase a large portion of native plant material for restoration purposes. In our study, only $19.4 \%$ of the respondents indicated that government agencies purchased material, while Brzuszek and Harkess (2009) found that government purchases only comprised $\approx 4 \%$ of sales in the southeast. In contrast, governmental agencies comprised 36\% of sales in Utah during 2000 (Hooper, 2003), and the Bureau of Land Management and U.S. Forest Service were the top two customers in western states during 2006 (Lynn et al., 2008; Peppin et al., 2010). Dunne and Dunne (2003) also noted that governmental purchases of native plant material increased from 30\% to $75 \%$ from 1990 to 2000.

Although demand may be low, our survey indicates that native nursery businesses do not rate price highly as a limitation. Yue et al. (2011) found that customers were willing to pay more for native/noninvasive plants compared with nonnative or invasive plants. In addition, Curtis et al. (2005) reported that $\approx 31 \%$ of Nevada homeowners were willing to pay $20 \%$ more for plants labeled "Nevada Grown."

In our survey, accurate labeling or indicating that plants are native was considered a very important factor for helping to increase production and sales of FNWs. Several native plant 
groups have seen more customer interest due to labeling plants as native (Curtis et al., 2005; Meyer, 2005; Yue et al., 2011). The "Nevada Grown" label is a government sponsored program that is third-party certified (Curtis et al., 2005), while "Utah's Choice" program is marketed by the Intermountain Native Plant Growers Association (Meyer, 2005). In contrast, Brzuszek and Harkess (2009) and Waterstrat (1997) indicated that $\approx 50 \%$ of the nurseries they surveyed did not label plants native, while only $21 \%$ of those surveyed by Brzuszek and Harkess (2009) did provide native plant identification on containers.

Low seed supply could also be affecting the FNW market in Florida. About $54 \%$ of the survey respondents indicated that a low seed supply limits the market, while $82 \%$ indicated that a reliable seed source was crucial for the sales and production of FNWs. A reliable seed supply may be a regional concern considering only $27 \%$ of nurseries in northern Arizona region considered availability a limiting factor (Lynn et al., 2008). Only 8\% of nurseries in the Colorado Plateau region considered seed supply the most important limiting factor (Peppin et al., 2010). Given that many nurseries grow FNWs from seed, creating a reliable seed source is critical. While many collect seeds from their own on-site crop, the small FNW inventory of many nurseries could be responsible for an unreliable seed supply.

About 50\% indicated that seed conditioning, breaking dormancy, testing seed viability, and maintaining seed viability were difficult or very difficult. Considering that over $50 \%$ of the respondents collect and store their own seed, we were not surprised that industry considered these important areas of research. While many nurseries in our study do not condition their own seeds, $\approx 61 \%$ considered conditioned seeds valuable to the FNW market. Industry members indicated that they were likely or very likely to purchase certified seed at a $50 \%$ price increase over noncertified seed. Jones and Young (2005) and Lynn et al. (2008) contend that the development of native seed certification policies will ensure that demand is being met.

Not only has demand for native seeds increased but also demand for locally sourced native plant material. 
Over half of the survey respondents were concerned or very concerned with the origin of their plant material. This is a rather low percentage compared with the $93 \%$ who were concerned with locality in a study by Peppin et al. (2010). Our survey indicates that lack of knowledge regarding ecotypes is not a concern: almost half classified an ecotype as a plant within the region. This is an appropriate definition according to Hufford and Mazer (2003) who defined ecotypes as "distinct genotypes (or populations) within a species, resulting from adaptation to local environmental conditions; capable of interbreeding with other ecotypes or epitypes of the same species." Although respondents in our study indicated a concern for using locally adapted plant material, 20.0\% purchase FNWs from out-of-state growers and producers. Although this is concerning, the percentage is much lower than the $44 \%$ of growers the Great Basin or Colorado Plateau who purchase from out-of-state producers (Lynn et al., 2008). Several authors have discussed the genetic implications of using seeds of domesticated wildflowers or seeds from nonlocal sources for restoration and conservation purposes (Broadhurst et al., 2008; Johnson et al., 2010; Jones and Monaco, 2009; Lesica and Allendorf, 1999).

As in Peppin et al. (2010), many respondents in our study indicated that local environmental conditions such as soil type, climatic conditions, and topography all influenced ecotypic development. The lower concern for ecotypes in our study could be due to cost of production or lack of availability. Peppin et al. (2010) reported that $50 \%$ and $22 \%$ of their survey respondents indicated that lack of availability and cost, respectively, prohibited buying and using local genotypes. However, over $80 \%$ of our survey respondents thought that the need for local FNWs in the next 5 years was important or very important. This reflects a similar trend as reported in Peppin et al. (2010) that $87 \%$ of buyers and $80 \%$ of producers recognized the need for local genotypes.

To successfully implement and promote a native wildflower or native plant market, education of both consumers and the industry is crucial. In our survey, $91.0 \%$ and $93.0 \%$ of the respondents indicated that education of industry and public, respectively, were very important or important for the FNW market. Brzuszek and Harkess (2009) reported that $\approx 54 \%$ of nurseries in the southeastern United States indicated that better consumer education would help increase native plant sales. In addition, Woosaree (2000), Meyer (2005), Peppin et al. (2010), and Pérez et al. (2010) all suggested that educating consumers on the use of native plants would bring awareness to the native plant market.

In Florida, native plant industry members have high expectations for the market. Creating and maintaining partnerships among growers, government agencies, educators, and researchers are necessary to promote better marketing and educational programs (Curtis et al., 2005; Lynn et al., 2008; Meyer, 2005; Pérez et al., 2010). In addition, strengthening the wildflower grower cooperative in Florida, similar to the Intermountain Native Plant Growers Association (Meyer, 2005), could aid in generating a reliable seed supply of both in demand and rarer FNWs. Although adoption and promotion of native plant use has been somewhat slow in the horticulture industry, consumers are willing to purchase native plants (Gagliardi and Brand, 2007; Yue et al., 2011). By educating consumers and the industry about FNWs, a stronger demand can be created that will continue to increase the FNW market.

\section{Literature cited}

Alabama Cooperative Extension System. n.d. Watershed and Stream Restoration in Alabama: General Information. 5 May 2011. <http://www.aces.edu/waterquality/ streams/general.htm>.

Black, M., J. Bewley, and P. Halmer. 2006. The encyclopedia of seeds: Science, technology and uses. CABI, Wallingford, UK.

Broadhurst, L., A. Lowe, D. Coates, S. Cunningham, M. McDonald, P. Vesk, and C. Yates. 2008. Seed supply for broadscale restoration: Maximizing evolutionary potential. Evol. Applications 1: 587-597.

Brooker, J., D. Eastwood, C. Hall, K. Morris, A. Hodges, and J. Haydu. 2005. Trade flows and marketing practices within the United States nursery industry: 2003. Tennessee Agr. Expt. Sta., Southern Coop. Ser. Bul. 404.

Brzuszek, R.F. and R.L. Harkess. 2009. Green industry survey of native plant marketing in the southeastern United States. HortTechnology 19:168-172.

Brzuszek, R.F., R.L. Harkess, and S.J. Mulley. 2007. Landscape architects' use of native plants in the southeastern United States. HortTechnology 17:78-81.

Curtis, K., M. Cowee, and S. Slocum. 2005. Nevada wildland seed cooperative feasibility assessment. Univ. Ctr. Econ. Dev., Dept. Resource Econ., Univ. of Nevada, Reno, NV.

Dillman, D. 2000. Mail and internet surveys: The tailored design method. 2nd ed. Wiley, New York.

Dunne, R. and C. Dunne. 2003. Trends in the western native plant seed industry since 1990. Native Plants J. 4:88-94.

Executive Order 13112. 1999. Invasive species. 5 May 2011. <http://frwebgate.access. gpo.gov $/$ cgi-bin $/$ getdoc.cgi? dbname= 1999_register\&docid=99-3184-filed.pdf .

Gagliardi, J.A. and M.H. Brand. 2007. Connecticut nursery and landscape industry preferences for solutions to the sale and use of invasive plants. HortTechnology 17:39-45.

Harper-Lore, B. and M. Wilson. 2000. Roadside use of native plants. Island Press, Washington, DC.

Hodges, A. 2011. Production and marketing practices in the Florida nursery industry, 2008. Dept. Food Resource Econ., Florida Coop. Ext., Inst. Food Agr. Sci., Univ. of Florida, Gainesville, FL.

Hodges, A. and J. Haydu. 2000. Economic impact of Florida's environmental horticulture industry. J. Environ. Hort. 18:123-127.

Hodges, A. and J. Haydu. 2006. Economic impacts of the Florida environmental horticulture industry in 2005. Dept. Food Resource Econ., Florida Coop. Ext., Inst. Food Agr. Sci., Univ. of Florida, Gainesville, FL.

Hooper, V. 2003. Understanding Utah's native plant market: Coordinating public and private interest. Utah State Univ., Logan, UT, MS Thesis.

Hufford, K.M. and S.J. Mazer. 2003. Plant ecotypes: Genetic differentiation in the age of ecological restoration. Trends Ecol. Evol. 18:147-155.

Johnson, R., L. Stritch, P. Olwell, and S. Lambert. 2010. What are the best seed sources for ecosystem restoration on BLM and USFS lands? Native Plants J. 11:117131.

Jones, T. and S. Young. 2005. Native seeds in commerce: More frequently asked questions. Native Plants J. 6:286-293. 
Jones, T. and T. Monaco. 2009. A role for assisted evolution in designing native plant materials for domesticated landscapes. Front. Ecol. Environ 7:541-547.

Lesica, P. and F. Allendorf. 1999. Ecological genetics and the restoration of plant communities: Mix or match? Restor. Ecol. 7:42-50.

Lowery, C. 1983. Wild flowers: An aesthetic way of conserving water and fuel in Florida. Proc. Florida State Hort. Soc. 96:178-180.

Lynn, J.C., W. Auberle, D.L. Peppin, P. Fule, and A.L. Mottek-Lucas. 2008. Northern Arizona native plant market feasibility study. Northern Arizona Univ., Flagstaff, AZ.

Meyer, S. 2005. Intermountain native plants growers association: A nonprofit trade organization promoting landscape use of native plants. Native Plants J. 6:104107.

Milstein, G. 2005. The uses and potential of wildflower seed in landscaping, p. 3941. In: M. McDonald and F. Kwon (eds.). Flower seeds biology and technology. CABI, Wallingford, UK.
National Wildlife Federation. 2007. American Beauties ${ }^{\mathrm{TM}}$. National Wildlife Federation, Reston, VA.

Norcini, J. 2006. Native plants: An overview. Dept. Environmental Hort., Florida Coop. Ext., Inst. Food Agr. Sci., Univ. of Florida, Gainesville, FL.

Peppin, D.L., P.Z. Fulé, J.C. Lynn, A.L. Mottek-Lucas, and C. Hull Sieg. 2010. Market perceptions and opportunities for native plant production on the southern Colorado plateau. Restor. Ecol. 18:113124.

Pérez, H.E., C.R. Adams, M.E. Kane, J.G. Norcini, G. Acomb, and C. Larsen. 2010. Awareness of and interest in native wildflowers among college students in plant-related disciplines: A case study from Florida. HortTechnology 20:368376.

Potts, L.E., M.J. Roll, and S.J. Wallner. 2002. Colorado native plant survey-Voices of the green industry. Native Plants J. $3: 121-125$.

Richards, R., J. Chambers, and C. Ross. 1998. Use of native plants on federal lands: Policy and practice. J. Range Mgt. 51:625-632.

Tamimi, L. 1999. The use of native Hawaiian plants by landscape architects in Hawaii. Virginia Polytechnic Inst. State Univ., Blacksburg, VA, MS Thesis.

Vasquez, L. and J. Haynes. n.d. Solutions for your Life: Lawn and Garden Publications. 5 May 2011. <http://miami-dade. ifas.ufl.edu/pdfs/fyn/Native-Nurseriesin-South-Florida.PDF>.

Waterstrat, J. 1997. Assessment of the native plant market in the southeastern United States. Mississippi State Univ., Starkville, MS, MS Thesis.

Woosaree, J. 2000. Market assessment of the native plant industry in western Canada. Alberta Environ., Alberta Agr. Food Rural Dev., Alberta Res. Council, Vegreville, AB, Canada.

Yue, C., T.M. Hurley, and N. Anderson. 2011. Do native and invasive labels affect consumer willingness to pay for plants? Evidence from experimental auctions. Agr. Econ. 42:195-205. 